\title{
胸椎部靫帯骨化症の術後検討
}

\author{
熊本中央病院整形外科 \\ 浦 田伸一・前川清 継 \\ 坂田 浩 章. 岡 嶋 啓一郎 \\ 高 野 晴 夫・川添泰 弘
}

\section{Operative Results for Ligamentous Ossification in the Thoracic Spine}

by

Shin'ichi Urata, Kiyotsugu Maekawa, Hiroaki Sakata, Keiichiro Okajima, Haruo Takano and Yasuhiro Kawazoe

Department of Orthopedic Surgery,

Kumamoto Chuo Hospital, Kumamoto, Japan

We surgically treated 20 cases of thoracic myelopathy caused by ossification of the yellow ligament (OYL) and combined OPLL. Subjects included 10 males and $10 \mathrm{fe}$ males. The duration between the occurrence of symptoms and time of surgery ranged from 1 month to 2 years (average 8.3 months).

The average age at surgery was 58 years. All patients had had laminectomy. We found difficulty in some cases in performing decompression of the ossified spinal lesions.

Key words : ossification of yellow ligament (黄色靶帯骨化症), ossification ofposterior longitudinal ligament (後縦靬帯骨化症), thoracic myelopathy（胸椎部脊髄症）, operative results（手術成績）

はじめに

胸椎部勒带骨化症は稀な疾患であるが, 進行すれば 痓性対麻㾇を来すことがある，今回，当院にて過去 15 年間に手術治療を行った症例につき検討を行った。

\section{対象及び方法}

症例は 20 例，男 10 例，女 10 例である. 年齢は 46 才 77 才, 平均 58 才. 術後経過観察期間は 2 力月〜 12 年, 平均 5 年 7 力月.

結果

\section{（1）臨床症状}

初発症状は, 下肢しびれ感 15 例, 知覚低下 2 例, 筋力低下を主訴とした物もあった。発症から手術まで の期間は 1 力月 2 年, 平均 8.3 力月. 術前症状は, 脱力 8 例, しびれ感 14 例で歩行障害が出現していた。
骨化のレベルは, OPLL 単独例は, 頝椎から連続 しているか, あるいは上位胸椎に存在, OYL との合 併例は中～下位胸椎に, OYL 単独例は全例下位胸椎 に存在していた（図 1).

(2) 神経学的所見

筋力低下 17 例, 全例股関節から存在し, 筋力 3 以 下が 13 例にみられた，知覚低下は 17 例，下位胸椎病 変 13 例では病巣より $1 \sim 2$ 䯣節下位, 上中位胸椎病 変 4 例ではそれ以上下位に存在していた。 下肢深部腱 反射は PTR は全例立進, ATR は 3 例が正常〜低下 を示し, 腰部脊柱管狭窄症の合併が示唆された。バビ ンスキー徵候は全例陽性であった。

\section{（3）手術と術後成績}

手術は全例に黄色靫帯骨化を含めた椎弓切除術を行っ た. 1 例に後側方より OPLL の削除, 局所後弯が進 行した 1 例に前方固定を追加した。手術時間は平均 2 時間 48 分, 出血量は平均 $423 \mathrm{~g}$. 術後歩行状態は 19 


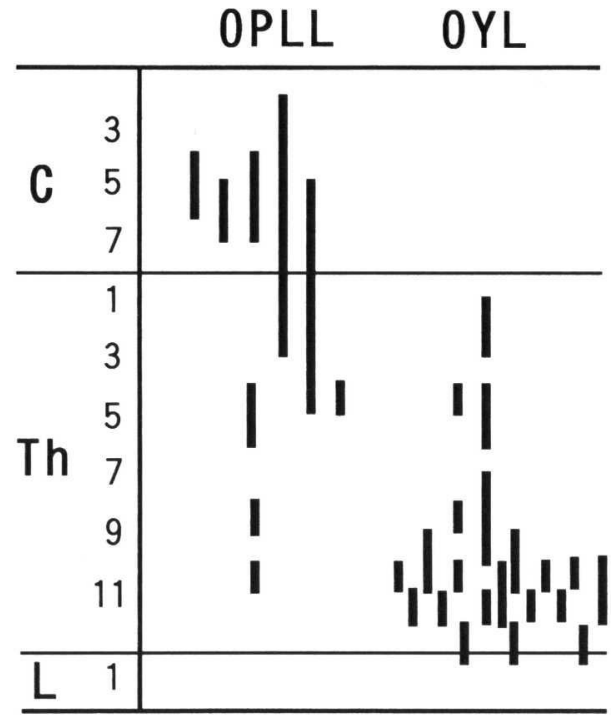

図1骨化レベルとしては，OPLL 単独は䅡椎から 連続しているか上位胸椎, OYL 単独は下位胸 椎, OPLL と OYL 合併例は中位一下位胸椎に 存在.

\section{歩行状態}

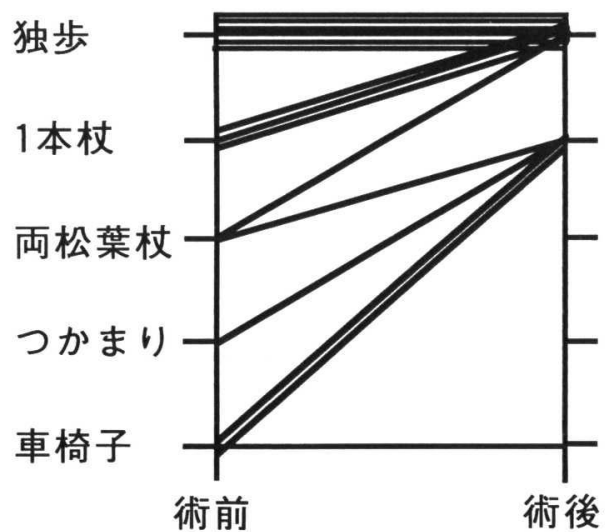

図 2 手術前後の歩行状態は 1 例を除き一本杖以上に 改善.

例が一本杖歩行以上に改善, 1 例が車椅子のままであっ た（図 2).

局所後弯は 2 年以上経過でもあまり進行していなかっ たが，1例に 15 度以上の後弯の増強があった（図 3 ).

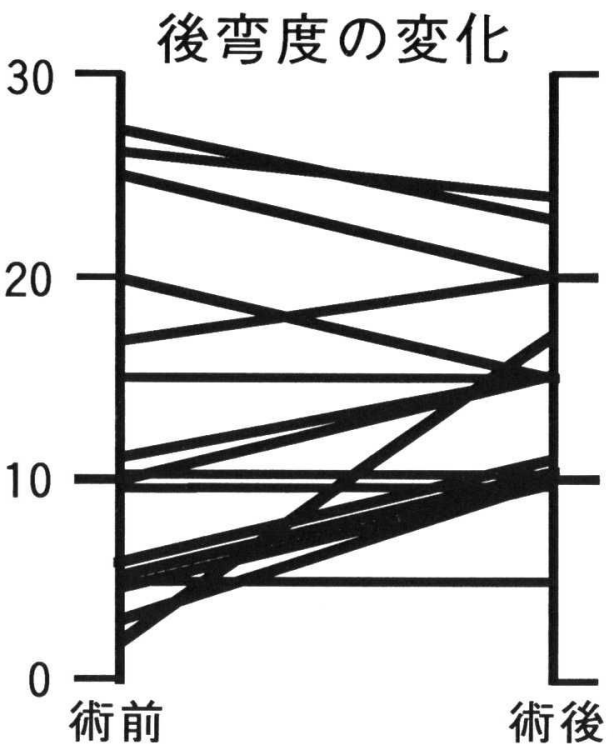

図 3 手術前後の局所後弯度は 2 年以上経過例でも著 しい変化はみられなかった。

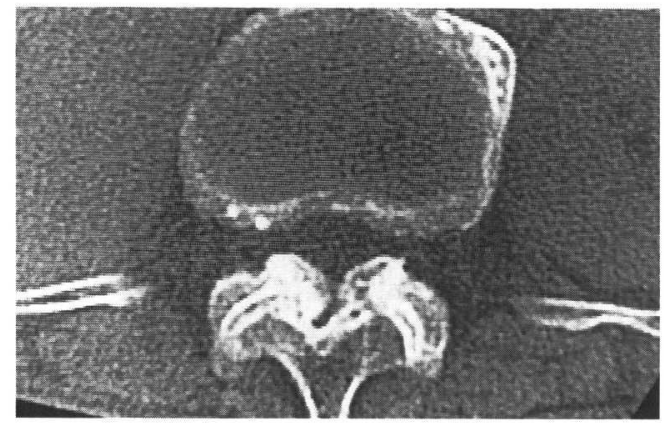

図 4 CT では骨化は右に強く，椎間関節 $1 / 3$ までい たる。

症 例 提 示

症例： 48 才，女性

主訴：歩行困難，両下肢痛及びしびれ．

現病歴： 2 力月前より安静時の両下肢のしびれで発症. しびれは上行し増強した. 1 力月前より下肢脱力出現, つかまり歩きで入院となる.

入院時所見: 筋力は両股関節以下 3 レベル, 下肢腱反 射は交進し，バビンスキー，クローヌスも認める。知 覚は L 2 以下に知覚低下を認め, 特に深部知覚の障害 が強かった。 


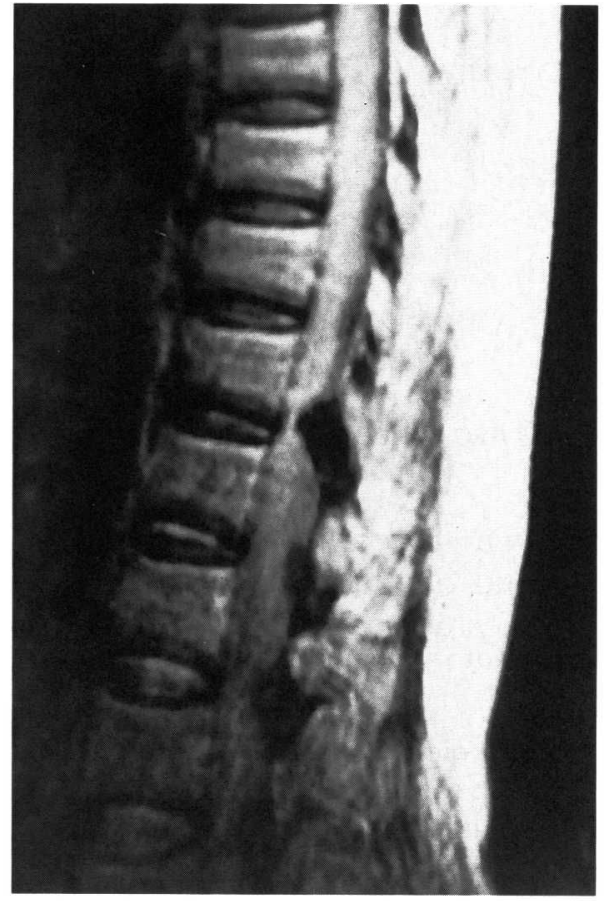

図 5 MRIでは，T 2 にて後方より圧迫著明，下位 胸椎にも軽度圧迫を認める。

画像診断：単純 X 線で Th 11-12 間に OYL を認め, CT では右に強い側方型で椎間関節 $1 / 3$ まで至ってい る(図 4).下行性脊髄造影では同部位での先細りの 完全ブロックを認める. MRI では T2 像にて後方よ り骨皮質の intensity での圧排が著明で 1 レベル下位 にも軽度圧迫を認める（図 5 ).

手術及び術後経過：Th 11，12 椎弓切除を行い, 一 本杖歩行にて退院したが術後 2 年にても痤性が残存し た。

\section{考察}

胸椎の後縦䩲帯骨化及び黄色䩲帯骨化は脊柱管狭窄 をきたして重篤な下肢の神経症状を来すことが多い. 神経症状が出現した症例に対しては手術療法が必要で ある ${ }^{4)}$. しかしながら胸椎部は生理的に後弯を呈し，
金柱管も比較的に狭小であり，手術に際しては注意を 要する.

当科にては椎弓切除術を行ってきたが, 後弯が強い 中位胸椎の症例で椎間関節の切除範囲を大きくせざる を得なかった症例では, 後弯形成が高度となり一旦は 平行棒内歩行まで回復したが, 麻痺が再悪化し, ハロー 装具 · 前方固定術の追加にもかかわらず再び車椅子と なった症例と, 下位胸椎で 4 椎弓切除を行った 9 年経 過症例で局所後弯が 15 度進行した症例の経験より, 当科の治療方針として OPLLの場合, 頚椎からの連 続型あるいは Th 3 までの症例では laminoplasty と laminectomy を, Th 4 以下では 2 椎間以内では前 方除圧固定術, 3 椎間以上では laminectomy と骨移 植を考えている. OPLL と OYL の同一レベルでの 合併では laminectomy と前方固定術の併用を考え ている2)3).

\section{ま と め}

(1) 胸椎靱帯骨化症の 20 例に椎弓切除術を施行, 術後成績を検討した。

(2) 初発症状としてはしびれ, 脱力感が多く, 手術 時症状としては歩行障害が多く, 術後 1 例を除き松葉 杖歩行以上となった.

(3)後縦鞋帯骨化症は顤椎から中位胸椎に, 黄色䩲帯 骨化症は下位胸椎に多かった。

(4)後弯が強度で中位胸椎にあるもの, 多椎間にわた るもの, 椎間関節切除が $1 / 2$ 以上必要な症例には骨移 植が必要と思われた.

\section{参 考 文 献}

1) 池上晃一ら：胸椎勒帯骨化症の 5 例, 中四整災誌, 4 : 289-292, 1992.

2）浪花慎悟ら：胸椎黄色䩲帯骨化症及び石灰化症に対す る手術症例の検討, 中四整災誌, 6:283-287, 1994.

3）諏訪勝保ら：胸椎黄色䩲帯骨化の手術成績, 整形外科 と災害外科, $43: 1326-1331,1994$.

4) 朝長匠ら：胸椎黄色靱带骨化症の術後成績, 整形外科 と災害外科, $42: 122-125,1993$. 